the diet free of gluten and cows' milk was the cause of his failure to thrive. The lack of new gastrointestinal symptoms and the normal results of investigations made allergy to the soybean protein an unlikely explanation for his weight loss.

The incidence of coeliac disease proved by jejunal biopsy in patients with eczema is less than $1 \% .^{2}$ There is no justification for withdrawing gluten unless malabsorption is present and coeliac disease is suspected, when prior jejunal biopsy is mandatory. Ingestion of cows' milk and infantile eczema are associated, ${ }^{3}$ and the many symptoms attributable to intolerance of cows' milk have received medical and public attention. ${ }^{45}$ The criteria for diagnosing intolerance to cows' milk are strict, ${ }^{4}$ and referral to hospital is reasonable when symptoms are persistent or severe, and essential if coeliac disease is suspected. Empirical changes in diet are sometimes necessary but should never be undertaken without careful review of weight gain. Complex alterations in diet should be undertaken only with the advice of a dietitian.

We thank Dr M Moncrieff for permission to report this case. WOT-M is supported by an Action Research training fellowship. 1 Tripp JH, Francis DEM, Knight JA, Harries JT. Infant feeding practices : a cause

2 Shuster S, Marks J. Systemic effects of skin disease. London: Heinemann Medical,

3 Atherton DJ, Sewell M, Soothill JF, Wells RS. A double-blind controlled crossover trial of an antigen avoidance diet in atopic eczema. Lancet $1978 ; 1: 401-3$. 4 Anderson CM, Burke V. Other disorders of the small intestine associated with malabsorption. In: Anderson CM, Burke V, eds. Paediatric gastroenterology. Oxford: Blackwell, 1975:229.

5 Carter J. Is your child allergic to milk ? Mother July 1983:53.

(Accepted 8 August 1984)

Paediatric Department, John Radcliffe Hospital, Oxford OX3 9DU WILLIAM O TARNOW-MORDI, MRCP, DCH, research fellow CATHERINE MOSS, BA, medical student

KAREN ROSS, SRD, paediatric dietitian

Correspondence to: Dr W O Tarnow-Mordi.

\section{Spontaneous choledochal-colonic fistula treated by duodenoscopic sphincterotomy}

Enterobiliary fistulas are a well recognised complication of cholelithiasis. ${ }^{2}$ The most common are cholecystoduodenal with cholecystocolonic being the second most common. Initially the complication was thought to be rare, but with the advent of endoscopic retrograde cholangiography the rate of recognition has increased.

We report a patient with a choledochal-colonic fistula secondary to cholelithiasis, diagnosed by barium enema and treated by duodenoscopic sphincterotomy.

\section{Case report}

An 87 year old woman presented with a six day history of central upper abdominal discomfort associated with nausea but no vomiting. She was of previous good health, except for mild congestive cardiac failure treated by a combined frusemide-potassium preparation (Lasikal, two tablets daily). Initial examination elicited epigastric tenderness but no rebound tenderness or guarding. There was no other physical abnormality. Biochemical investigation showed mild renal failure (plasma urea concentration $15.4 \mathrm{mmol} / \mathrm{l}$ $(93 \mathrm{mg} / 100 \mathrm{ml})$, creatinine concentration $178 \mu \mathrm{mol} / 1(2.0 \mathrm{mg} / 100 \mathrm{ml}))$, mild hypokalaemia (potassium concentration $3.0 \mathrm{mmol}(\mathrm{mEq}) / \mathrm{l}$ ), but normal sodium and chloride values. Plain abdominal radiographs were normal. Her diuretic was stopped.

The abdominal pain remained unchanged but she began to have watery diarrhoea with up to 10 bowel actions a day. The hypokalaemia worsened, with readings of $\mathbf{2} \cdot 4-2 \cdot 8 \mathrm{mmol} / 1$. Repeated measurements of liver function values were normal. Sigmoidoscopy to $20 \mathrm{~cm}$ showed normal appearances. Barium enema disclosed a choledochal-colonic fistula with two gall stones within the common bile duct (figure). An endoscopic cholangiogram confirmed these findings and at sphincterotomy $(1.5 \mathrm{~cm})$ one of the stones was removed. The second stone was not removed but the sphincterotomy was large enough to allow free drainage of bile and subsequent passage of the stone.

Over the next three days there was resolution of the diarrhoea and return to normal bowel action. The plasma potassium value rose to normal within
48 hours and was maintained without oral supplements. At outpatient review four and 12 weeks after the sphincterotomy she had remained well and was without symptoms.

\section{Comment}

Anatomical enterobiliary fistulas are not rare, being documented in $0.4 \%$ of cases at necropsy and in $13.6 \%$ of patients in one series examined by endoscopic retrograde cholangiography. ${ }^{3}$ Those requiring treatment, however, are uncommon; Glenn et al recorded

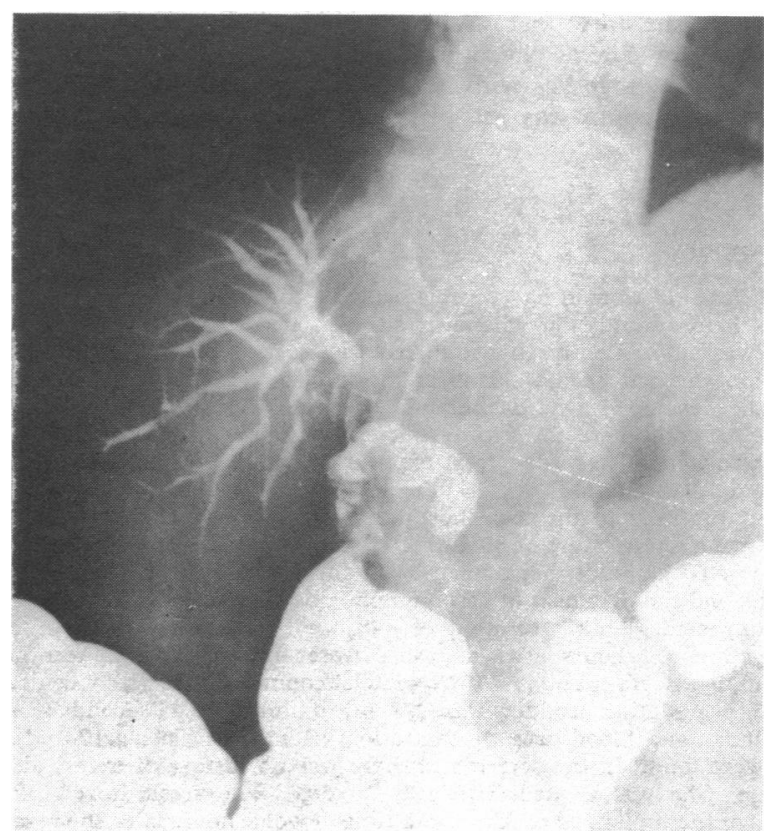

Spot film taken from barium enema examination showing choledochal-colonic fistula.

only 105 cases over 46 years at the Cornell Medical Center, New York. ${ }^{1}$ Most are seen in elderly people secondary to cholelithiasis but other causes are trauma, operative surgery, neoplasms, and peptic ulceration. Symptoms are non-specific but may be cholangitis, persistent diarrhoea, electrolyte imbalance, malabsorption, gall stone ileus, or very rarely major bleeding. ${ }^{4}$ Treatment in patients with symptoms has traditionally been open abdominal surgery with excision of the fistula or a drainage procedure, but this carries an operative mortality of $6 \%$ and morbidity of $15 \% .^{1}$

The removal of common bile duct stones by endoscopic methods is established practice with a morbidity of about $10 \%$ and mortality below $1 \%$. Endoscopic treatment of an internal biliary fistula has not been reported, though the same technique has been successfully used to treat an external fistula. ${ }^{5}$ We did not document the healing of the fistula in our patient but the resolution of her symptoms and rapid correction of the hypokalaemia made this likely. We suggest that endoscopic sphincterotomy should be considered in cases of symptomatic biliary fistulas, especially when major surgery is undesirable.

1 Glenn F, Reed C, Grafe WR. Biliary enteric fistula. Surg Gynecol Obstet 1981; 153:527-31. 2 Slasky SB, Campbell WL. Cholecystosigmoid fistula. Am f Gastroenterol 1983;

3 Ghazi A. Enterobiliary fistula and ERCP. Am $\mathcal{F}$ Gastroenterol 1977;68:81-3.

4 Kaplan BJ. Massive lower gastrointestinal hemorrhage from cholecystocolic Dis Colon Rectum 1967;10:191-7.

5 O'Rahilly S, Duignan JP, Lennon JR, O'Malley E. Successful treatment of postoperative external biliary fistula by endoscopic papillotomy. Endoscopy 1983;15:68-9.

(Accepted 8 August 1984)

Department of Medicine, Seacroft Hospital, Leeds 14

$P$ BANNISTER, $M B, M R C P$, tutor in medicine

C BENNETT, $M B$, CHB, senior house officer

M E DENYER, MB, MRCP, consultant physician

Correspondence to: Dr P Bannister, Department of Medicine, St James's University Hospital, Leeds. 